\title{
APPLICATION OF GOOGLE APP SCRIPTS IN EMAIL FOR PROVIDING CURRENT AWARENESS SERVICES TO RESEARCH SCHOLARS, AT CENTRAL UNIVERSITY OF KERALA: AN EVALUATIVE STUDY
}

\author{
Shri. Ashok Thomas \\ Professional Assistant \\ Central University of Kerala \\ Kasaragod Dt., Kerala, India
}

\author{
Ms. Priya K \\ Semi Professional Assistant \\ Central University of Kerala \\ Kasaragod Dt., Kerala, India
}

\author{
Ms. Sreeja K P \\ Library Assistant \\ Central University of Kerala \\ Kasaragod Dt., Kerala, India
}

\begin{abstract}
It is the responsibility of every Library to make its resources to be utilized to the maximum by its user community, as every education institution spends crore of amount for the purchase/ subscription of resources, which is very much crucial to optimize the research outputs. This paper discusses E- mail Information system developed at Central University of Kerala for providing CAS. With the application of G Suite, University Library is able to send $E$ mail up to 2000 per day. This paper also discusses about the utilization and benefits from this E -mail systems among Research Scholars at Central University of Kerala. The study comes to the finding that 86\% of research scholars are very much benefited by getting frequent CAS service through $\mathrm{E}$-mail.
\end{abstract}

Keywords-- E- mail Information System, G Suite, Google Script, Google Spread Sheet, CAS.

\section{INTRODUCTION}

The success of any higher education system depends on the research outputs they provide to the Nations. In order to provide quality research outputs, the higher education institutions has to make their community self-sufficient, by providing them with quality information which they can access from any corner of world.

Hence, the Library which is the heart of every education institution has key role in providing each bit of required information to its user community without any discrimationn like faculty, students, staffs etc. It is the responsibility of the Library to enrich the quality of research output by providing the user community with timely, complete, accurate and reliable information which they can access at their fingertips from any corner of the world.

Now a day, Library uses lots of technologies like [1] library's Website, e-mail lists, blogs and podcasts; print materials, such as posters, handouts and giveaways; events such as orientation tours and workshops; and other tools such as library publications, contests, brochures, direct mail, Web 2.0 applications and displays [1] etc. for providing effective Library services.

\section{LITERATURE REVIEW}

B. Kumara, Govanakoppa, Rajalaxmi \& M. Devendrappa. (2013) conducted a study titled Web based Library alert service: A study. This study discusses different kinds of alert services like citation alert, web alert, search alerts, publication alerts etc. These alert services provide, the brief awareness for researchers and other users about the Library resources. This study analyses advantage and disadvantage of the alert service

Hariharan, A., Hariharan, Chitra M., Mymoon, M, Abdunnasar, A. and Suryakala, S (2007) conducted a study on Customized Web-based Services at SERC Library with Special Reference to Alert Services. This paper discussed the using AutoLib library software and useful web-based library services. The paper also describes various alert services provided at SERE library. The study comes to the conclusion that web based service will provide easier access to digital collection.

Nisha Kumari (2016) conducted a study titled Web- based services in library and information science. This paper examines the web based library services, their features, advantages and disadvantages. This paper mainly discusses about various digital reference services like e-mail, Web forms, Web based user education, Ask- a- librarian services etc.

\section{OBJECTIVE OF THE STUDY}

The study is carried out with the following objective:

1. To find out the user satisfaction with Current Awareness Service provided by University Library through E- mail Information system. 


\section{International Journal of Engineering Applied Sciences and Technology, 2019 \\ Vol. 4, Issue 6, ISSN No. 2455-2143, Pages 313-318 \\ Published Online October 2019 in IJEAST (http://www.ijeast.com)}

2. To find out to what extend the Research Scholars get benefited by getting this service

3. To find out whether the CAS service is helpful for locating required information

4. Modification if any required in the present CAS.

5. To study about the present $\mathrm{E}$ mail delivery system at University Library, CUK.

\section{SCOPE}

The Central University of Kerala is investing Crore of amount for the purchase/subscription of library resource, hence it is the responsibility of the Library to make ensure that the resources are utilized to the maximum by its patrons. This study is very important, as the cost of the library resources is increasing considerably, Library should make its resources to be utilized to the maximum by displaying the resources at individual user's desk.

\section{METHODOLOGY}

In order to understand the effectiveness, user satisfaction of Current Awareness Services among the Research Scholars of Central University of Kerala, a study was conducted by distributing the questionnaire among 150 Research Scholars and by conducting personal interview with 50 Research Scholars of Central University of Kerala.

\section{CENTRAL UNIVERSITY OF KERALA}

The Central University of Kerala is one of the 16 Central Universities established under the Central Universities Act, 2009. The Central University of Kerala started functioning in March 2009 in Vidyanagar, Kasaragod with two academic programs M A English \& Comparative Literature and M A Economics under the School of Language \& Comparative Literature and School of Global Studies. Now the Central University of Kerala have 27 departments under 12 Schools at its own permanent campus in Periya, Kasaragod. In addition to this CUK has academic programmes at Capital Centre, Thiruvananthapuram and Law Campus at Thiruvalla.

\begin{tabular}{|c|c|c|}
\hline $\begin{array}{c}\text { Sl } \\
\text { No }\end{array}$ & Dept. & School \\
\hline 01 & $\begin{array}{l}\text { English \& Comparative } \\
\text { Literature }\end{array}$ & $\begin{array}{l}\text { Languages and } \\
\text { Comparative Literature }\end{array}$ \\
\hline $\mathbf{0 2}$ & Economics & Economics \\
\hline 03 & $\begin{array}{l}\text { Biochemistry and } \\
\text { Molecular Biology }\end{array}$ & Biological Science \\
\hline 04 & Zoology & Biological Science \\
\hline 05 & Genomic Science & Biological Science \\
\hline 06 & Physics & Physical Science \\
\hline 07 & Computer Science & Physical Science \\
\hline 08 & Hindi & $\begin{array}{l}\text { Languages and } \\
\text { Comparative Literature }\end{array}$ \\
\hline 09 & Mathematics & Physical Science \\
\hline 10 & Botony & Biological Science \\
\hline 11 & Chemistry & Physical Science \\
\hline 12 & Environmental Science & Earth Science Systems \\
\hline 13 & $\begin{array}{l}\text { International Relations } \\
\text { \& Politics }\end{array}$ & Global Studies \\
\hline 14 & Linguistics & $\begin{array}{l}\text { Languages and } \\
\text { Comparative Literature }\end{array}$ \\
\hline 15 & Social Work & Social Science \\
\hline 16 & Education & Education \\
\hline 17 & Law & Legal Studies \\
\hline 18 & Malayalam & $\begin{array}{l}\text { Languages and } \\
\text { Comparative Literature }\end{array}$ \\
\hline 19 & $\begin{array}{l}\text { Public Health \& } \\
\text { Community Medicine }\end{array}$ & Medicine \& Public Health \\
\hline 20 & $\begin{array}{l}\text { Public Administration } \\
\text { \& Policy Studies }\end{array}$ & Social Science \\
\hline 21 & Geology & Earth Science Systems \\
\hline 22 & Yoga & Medicine \& Public Health \\
\hline 23 & $\begin{array}{l}\text { BA International } \\
\text { Relations \& Politics }\end{array}$ & Global Studies \\
\hline 24 & Management Studies & Business Studies \\
\hline 25 & $\begin{array}{l}\text { Commerce and } \\
\text { International business }\end{array}$ & Business Studies \\
\hline 26 & Tourism Studies & Business Studies \\
\hline 27 & Kannada & $\begin{array}{l}\text { Languages and } \\
\text { Comparative Literature }\end{array}$ \\
\hline
\end{tabular}

Table 1: List of Departments at CUK

\section{UNIVERSITY LIBRARY, CENTRAL UNIVERSITY OF KERALA}

Central University of Kerala gives top priority in developing a new age Library. The present University Library system is so developed that it acts as a motivating and sustaining power in University's academic pursuit. The Library started functioning at Central University of Kerala in October 2009. Within a short period of time it has attained considerable level of development.

The Library of Central University of Kerala is automated with Koha Library Management Software and the classification scheme followed in Library is Dewey Decimal Classification 


\section{International Journal of Engineering Applied Sciences and Technology, 2019 Vol. 4, Issue 6, ISSN No. 2455-2143, Pages 313-318 \\ Published Online October 2019 in IJEAST (http://www.ijeast.com)}

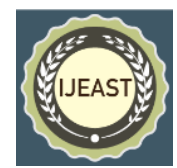

(DDC). The Library has a separate Digital Resource Centre to provide access to Internet and other digital resources.

The University Library of Central University of Kerala is a home for the largest collection of learning resources on arts, humanities, science and social sciences to support the research outputs. The Library resources of CUK are as follow:

\begin{tabular}{|c|l|l|}
\hline $\begin{array}{c}\text { Sl } \\
\text { No. }\end{array}$ & Resources & No.s \\
\hline 01 & Books & 42969 \\
\hline $\mathbf{0 2}$ & Print Journals & $\mathbf{8 5}$ \\
\hline $\mathbf{0 3}$ & E-journals & $\mathbf{1 0 0 0 0 +}$ \\
\hline $\mathbf{0 4}$ & Magazines & $\mathbf{4 8}$ \\
\hline $\mathbf{0 5}$ & News Papers & $\mathbf{1 8}$ \\
\hline $\mathbf{0 6}$ & Databases & $\mathbf{8}$ \\
\hline $\mathbf{0 7}$ & CD/DVD & $\mathbf{5 1 3}$ \\
\hline $\mathbf{0 8}$ & Theses & $\mathbf{1 7 5}$ \\
\hline 09 & Software & 1 \\
\hline
\end{tabular}

Table 2: List of Library Resources at CUK

The moto of the University Library, Central University of Kerala is to provide service to its users at their door, so that they will be more attracted towards Library and the Library resources will be utilized to its maximum by its user community. For making the concept fruitful the University Library is providing various facilities and services to its patrons' like:

$\begin{array}{ll}\text { - } & \text { Reference facility } \\ \text { - } & \text { Book Lending } \\ \text { - } & \text { OPeprography } \\ \text { - } & \text { Inter Library Loan } \\ \text { - } & \text { Library orientation, Library tours } \\ \text { - } & \text { Plagiarism checking etc. } \\ \text { - } & \text { Library publications } \\ \text { - } & \text { Workshops, Training programmes etc. } \\ \text { Alerting Services (User Group)- Current Awareness } \\ \text { Service } \\ \text { VIII. CURRENT AWARNESS SERVICES AT } \\ \quad \text { UNIVERSITY LIBRARY, CUK }\end{array}$

Current Awareness service is a service used to keep a user informed of new resources available in the Library. This service will help the Library to keep it users well-informed and up-to-date in their fields of interest as well as in related subjects, it is a system of getting knowledge on recent development, and especially those developments which related to the special interest of the individual.

There are lots of technologies like web sites, WhatsApp, E mail list, Internet etc. a Libraries can adopt to provide Current Awareness Service to its users, so that the Library resources will become their primary concerns to get the information in their respective field of interest.

E- mail is the one of the important technology adopted by the University Library for providing quality CAS service. Through this service the user community of Central University of Kerala is getting online help to locate the latest information, information resources in their area of interest.

The University Library is frequently providing Table of contents (TOC) alert and list of new arrivals of books through E- mail to the end users of the Library which includes Statutory Officers, Faculty, Research Scholars, Students, NonTeaching Staff and Outsourced Staffs. So, everyone who is become the part of the University will get this alerting services personally in their mail frequently.

\section{E mail- System in CUK}

Although University Library can adopt lots of technologies like websites, blogs, WhatsApp, etc. to provide CAS service, the prime importance was given to $\mathrm{E}$ mail based delivery system. It is a web based excellent, popular media and has got many advantages when compared to other services like websites and blogs etc.

Since 2010, the University Library, Central University of Kerala has started providing CAS using E- mail. In earlier times there was a google group for sending E- mail from infogroup cuklibusergroup@gmail.com to cuklibinfogroup@googlegroups.com, for providing alerting services to a group of students, Research Scholars, Staffs and Faculties. As the time passed there come lots of modification and alternation in the E- mail delivery system of University Library. Now each and every users of University Library have started to receive alerting services in their personal E- mail ids frequently with the application of Google GSuit, Google Script.

\section{Google GSuite}

G Suite ties all of Google's apps together into the original online office suite and it offers a simpler option, with one online account that gives you all apps in your teams' browsers. There's nothing to install, and in an hour or so, you can set up the entire set of software for your team. G Suite's individual apps are great on their own, modern tools with everything you need to make documents, spreadsheets, and presentations. The individual features aren't the main reason to use them, though.

What makes G Suite great is how it's built for collaboration. You can share your files with any one - even publicly on the web if you like-and let them all jump in and help craft a masterpiece. You can live-edit with others at the same time, or leave comments that Google will email for feedback later (even directly from the inbox-just reply to the email to reply 


\section{International Journal of Engineering Applied Sciences and Technology, 2019 Vol. 4, Issue 6, ISSN No. 2455-2143, Pages 313-318 \\ Published Online October 2019 in IJEAST (http://www.ijeast.com)}

to the document comment). And since $G$ Suite lives in the browser, it works anywhere, anytime. It can even work while you sleep. Add a Google Form to your Google Sheets spreadsheet and new answers will show up in your sheet automatically, ready the next time you $\log$ in. Add some addons and integrations to your G Suite account, and your Sheets can crunch numbers on their own. It's simpler to set up, simpler to administrate, with modern new tools that will help your team work together more efficiently. With G Suite, you'll get all of Gmail's features on your own domain, with your company's logo in the top left corner [3].

G-Suite for Education will be used to enhance teaching and learning in the school. School users will have access to a variety of core services offered by G-Suite including: Gmail (including Inbox by Gmail), Calendar, Chrome Sync, Classroom, Contacts, Drive, Docs, Forms, Groups, Sheets, Sites, Slides, Talk/Hangouts and Vault [4,5].

\section{Google Script}

Google Apps Script is the most powerful tool in the Google prodects. Google Apps Script is a JavaScript cloud scripting language that provides easy ways to automate tasks across Google products and third party services and build web applications. Apps Script runs exclusively on Google's infrastructure requiring no server provisioning or configuration. In practice writing Apps Scripts are simple.

Google Apps Script does not require setup or installation. The only requirement is a Google Account. A Gmail account works as well as a Google Apps for Work/Education/Government account. You can create a new Google account by going to accounts.google.com. For app-scripts to run they must contain a code.gs file. The code.gs file must contain a function named doGet (standalone scripts) or an onOpen function (addon scripts) [6].

\section{Types of scripts}

Google App scripts are of three types.

A. Standalone- Standalone scripts are not bound to any Google apps i.e Docs, Sheets or Forms etc.

B. Bound to Google Apps - Script bound to Google Apps also known as container-bound script; unlike standalone scripts, are bound to Google apps i.e Google Docs or Google Sheets etc.

C. Web Apps - Google App Script can be used as web app as they can be accessed by browser.

\section{Scripts used in email information system}

A. MailApp is the api from Google App Script that can be used to send mail

function sendEmails() \{

var subject $=$ "A subject for your new

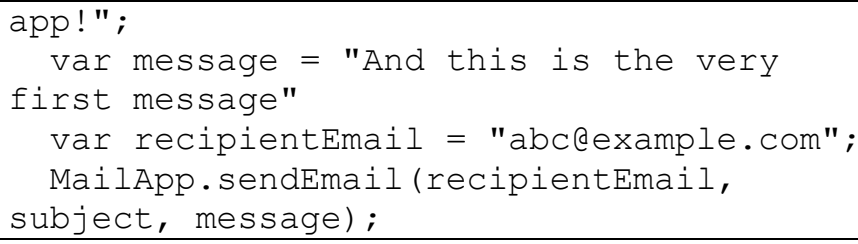

The MailApp Class is limited to quotas based on your Google Account:

- Consumer user (ie, personal Gmail account): 500

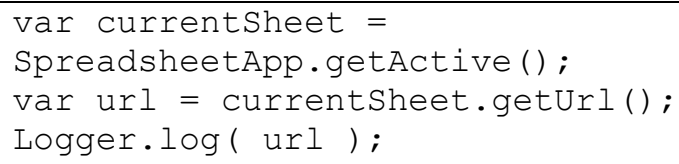

- Google Apps (legacy) customer:5 00 recipients/day

- GSuite (basic/Gov/Edu/Business): 2000 recipients/day

\section{B. SpreadsheetApp Active Sheet}

\section{Get all Files in a Drive Folder}

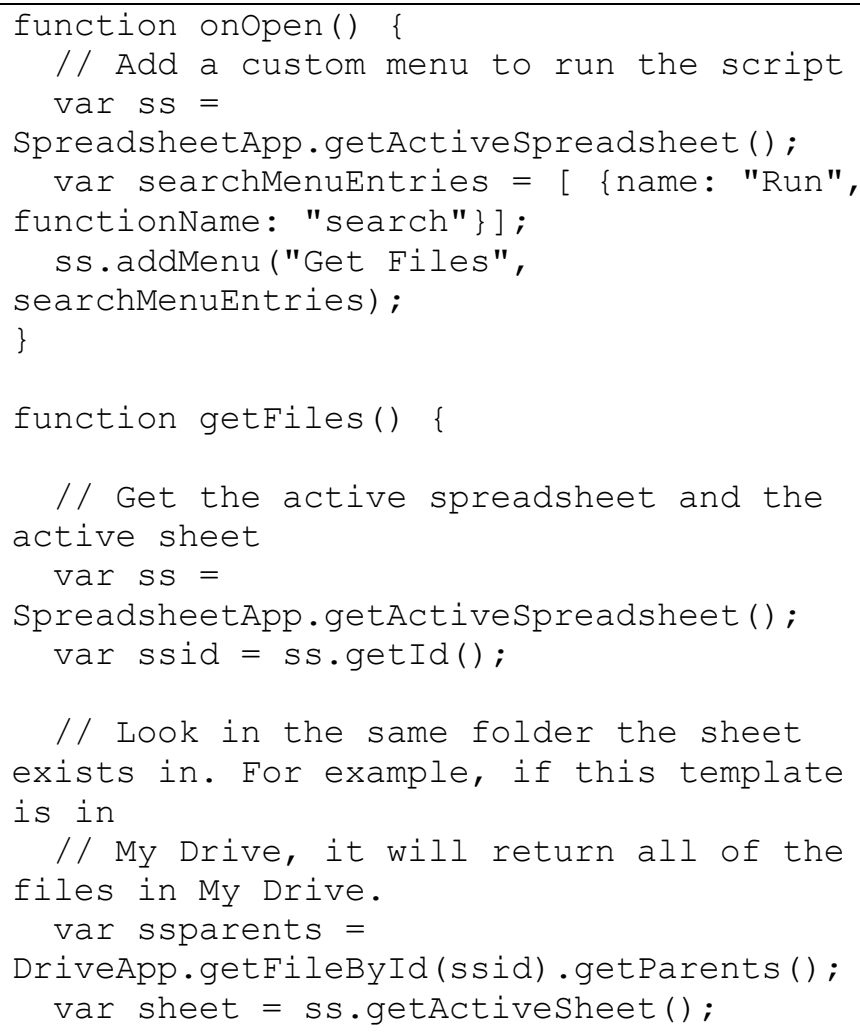




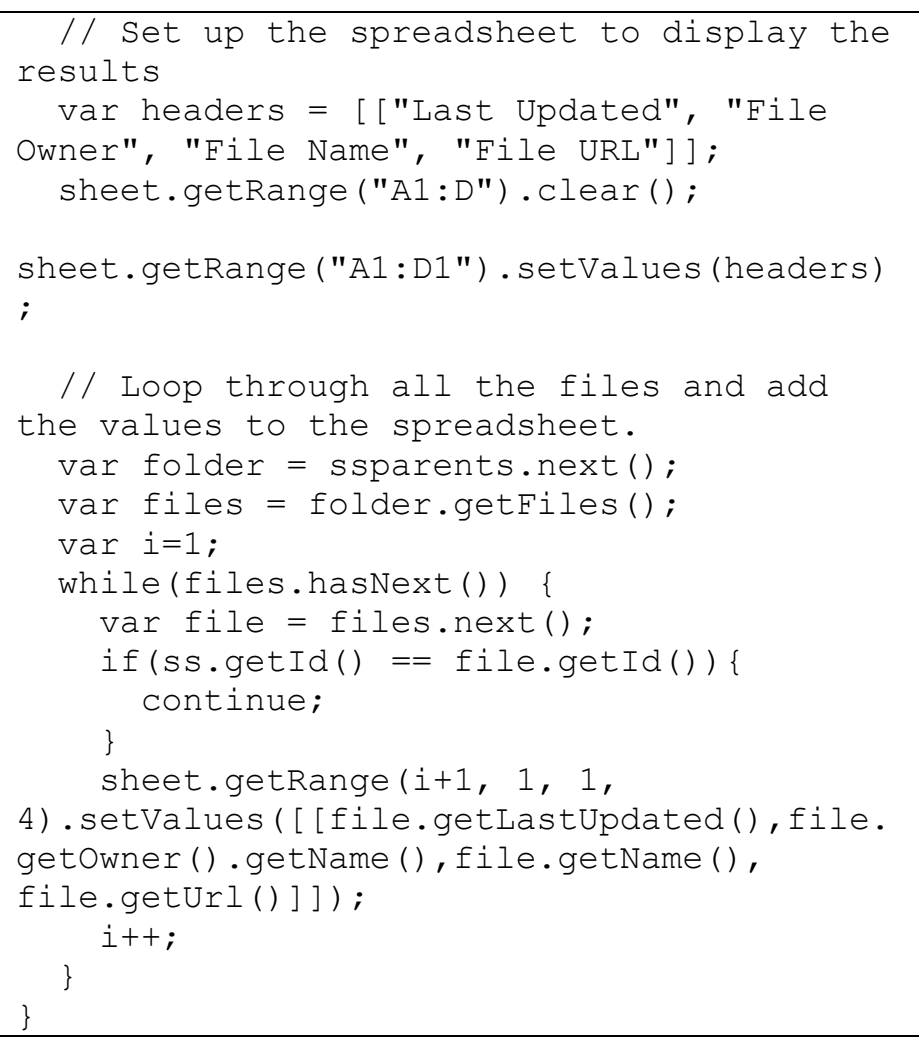

With the use of above mentioned Google App Scripts, University Library is able to send E- mails up to 2000 people at a time in a single click. Even a person with basic knowledge in Excel can implement this easily with the Technical Assistance from IT Technician.

By following this method one can easily:

$>$ Send email up to more than 2000 people at a time in a single click.

$>$ Easily delete or add particular group of people, as it is in spread sheet.

$>$ Easily block or select certain group of people just with one click.

$>$ By enabling double checking in spread sheet one can easily ensure that particular mail has sent to the concerned person or not

$>$ Ensure that, the same mail cannot be send twice to a person, as the system automatically block the repeated mail to the same person.

$>$ Ensure that E- mail Information System is working with the Google Security

\section{FINDINGS}

The study has come to the following findings:
1. $86 \%$ Research Scholars responded that the CAS Provided through E- mail from University Library is useful to their research work

2. $76 \%$ Research Scholars says that the service is useful to update their knowledge other than their subject area and the service very helpful to track the back volume articles also.

3. $73 \%$ Research scholars are very much satisfied with the present E- mail system and only $26 \%$ requested to provide the CAS service through WhatsApp and Face Book

4. 53\% Research Scholars said that they are getting closer to the society through getting TOC of general magazines.

5. Most of the research scholars i.e. 66\% responded that they did not used to get any type of CAS service from their previous studied institution

It has also found that $\mathrm{E}$ mail is the best way to communicate the arrival of new addition of books, magazines and journals to the user community. It is very simple and easy to handle. One can send 10,000 mail per day with a single click. When compared to WhatsApp, Blog and Website which require continuous monitoring and updating, otherwise the service will be useless. whereas the WhatsApp is concerned we can communicate with the limited number of users only $\mathrm{E}$ mail is the most proper, secured, personal service to the user communities.

\section{FUTURE PLAN}

The future plan of the University Library is to distribute the Table of Contents (TOC) of e-journals and e-books, so that all the resources of the University Library is utilized to the maximum by its user community. In future the University library users will be able to get the TOC of periodicals, magazines, e journals, e books and new addition alert of books at their desk in their personal mail.

\section{CONCLUSION}

With the applications of Google Apps Script which is available free of cost for education institution, the users of University Library, Central University of Kerala is started to get more useful services. By using Google Apps, the University Library is able to reach its each and every user within a short period of time in a cheapest way and it is the most secured and suitable way also. If it is applied in all education institution the research will be more effective and fruitful.

\section{Abbreviation: -}

- $\quad$ CUK- Central University of Kerala

- $\quad$ CAS- Current Awareness Service

- $\quad$ E-mail- Electronic Mail

- TOC- Table of Content 


\section{International Journal of Engineering Applied Sciences and Technology, 2019 \\ Vol. 4, Issue 6, ISSN No. 2455-2143, Pages 313-318 \\ Published Online October 2019 in IJEAST (http://www.ijeast.com)}

\section{ACKNOWLEDGEMENT}

We would like to thank all our Research Scholars and colleagues for their valuable suggestions. We also express our gratitude to our parents, friends and Library users.

\section{REFERENCES}

[1] Zhixian Y. (2016).Effective techniques for the promotion of library services and resources, Information Research, 21(1). Retrieved from https://files.eric.ed.gov/fulltext/EJ1094561.pdf

[2] Mishra, Lakshmikant and Mishra, Jyoti. (2014). ICT Resources and Services in University Libraries, International Journal of Digital Library Services, 4(3), pp. 243-250. Retrieved from http://www.ijodls.in/uploads/3/6/0/3/3603729/22434.pdf

[3] Retrieved from https://cdn.zapier.com/storage/learn _ebooks/66c3a6e092e0ee3771050331df69cbda.pdf

[4] Retrieved from https://sssc.vic.edu.au/wpcontent/uploads/2017/10/Privacy-Impact-AssessmentGo-ogle-G-Suite-for-Education.pdf

[5] Retrieved from https://www.kenet.or.ke/sites/ default/files/understanding_google_apps_for_educatio n_0.pdf

[6] Retrieved from https://riptutorial.com/google-appsscript/example/17194/web-app-form

[7] Retrieved from http://shatua.tripod.com/DRTC seminar.html\#semi3.5

[8] Retrieved from https://automatetheboringstuff .com /chapter16/

[9] B., Kumara, Govanakoppa, Rajalaxmi \& M., Devendrappa. (2013). Web based Library alert service: A study. International Conference on Digital Libraries, New Delhi. Available at: https://www.researchgate.net/publication/259400238 (accessed $25^{\text {th }}$ September 2019).

[10] Hariharan, A., Hariharan, Chitra M., Mymoon, M, Abdunnasar, A. and Suryakala, S. (2007). Customized Web-based Services at SERC Library with Special Reference to Alert Services. DESIDOC bulletin of information technology, 27(3), pp. 31-38.

[11] Han, Lifeng \& Goulding, Anne. (2003). Information and reference services in the digital library. Information Services \& Use, 23(4), pp. 251-262.

[12] Zhixian Yi (2016). Effective techniques for the promotion of library services and resources. Information Research, 21(1), retrieved from
http://InformationR.net/ir/21-1/paper702.html (Archived by WebCite ${ }^{\circledR}$ at http://www.webcitation.org/6fq4XvwUf).

[13] Nisha Kumari (2016). Web- based services in library and information science. International Journal of Next Generation Library and Technologies, 2(1), pp. 1-18. http://www.ijnglt.com/files/Vol\%202\%20Issue\%201/Ni sha\%20Kumari.pdf

[14] Ferreira, James (2014). Google Apps Script:web application development essentials, $\left(2^{\text {nd }}\right.$ ed, pp.1200).Beijing :O’Reilly Media Inc.

[15] Kaur, Kiran and Singh, Diljit (2011). Customer Service for academic library users on the web, The Electronic Library 29(6), pp.737-750.Retrieved fromhttps://pdfs. Semanticscholar .org/96cb/f2da1f7 b3030420b6dcc 29045eddf5abf1d9.pdf 